\title{
PRESIDENCY OF THE REPUBLIC OF CROATIA TO THE COUNCIL OF THE EUROPEAN UNION IN 2020 - A CHALLENGE FOR THE REPUBLIC OF CROATIA
}

\section{Suzana Dikonić, LLM}

Vinkovci city investment and development agency VIA Ltd.

Vatrogasna 5, Vinkovci, Croatia

suzana.cutura@gmail.com

\section{Danijela Slipčević, LLM}

Vinkovci city investment and development agency VIA Ltd.

Vatrogasna 5, Vinkovci, Croatia

danijela.slipcevic@viavinkovci.hr

\author{
Marko Dikonić, LLM \\ Vukovar-Srijem County \\ Županijska 9, Vukovar, Croatia \\ marko.dikonic@vusz.hr
}

\begin{abstract}
The Republic of Croatia will chair the Council of the European Union from 1 January to 30 June 2020, within the framework of the Joint Presidency Programme with Romania and Finland for a period of 18 months. On 5 July 2018, the Government of the Republic of Croatia adopted a Decision on the Establishment of the Structure for the Preparation and Implementation of the Presidency of the Republic of Croatia of the Council of the European Union in 2020 and declared all preparatory activities for the Presidency to be of special importance for the Republic of Croatia. It is anticipated that around 1,400 meetings will be held in Brussels during the presidency of the Republic of Croatia, along with 1 to 2 summits of Heads of State and Government of the EU member states, about 20 meetings and conferences at the ministerial level and about 200 lower level meetings. Given the requirements and the necessary preparatory and especially implementation activities and a relatively short time for preparation and organization, we believe that the presidency will be a major financial, organizational, logistical, personnel and political challenge for the Government and the Republic of Croatia. On the other hand, the presidency is a chance and an opportunity for the Republic of Croatia to influence the creation and direction of common European policies. Since the Slovenia encountered similar challenges when they have been chairing the Council of the European Union for the first time, we will look at their problems and solutions.
\end{abstract}


The purpose of the research is to identify the key challenges and problems the Republic of Croatia will face when organizing and implementing the Presidency of the Council of the European Union.

The aim of the paper is to make recommendations and to define the specific conditions that must be met to successfully organize and implement the Presidency of the Republic of Croatia of the Council of the European Union.

Establishment of the presented governance structure of the Croatian Presidency can be positively assessed and it can be assumed that for the successful preparation and implementation of the Presidency of the Council, it is good that the members of the governing body are high-ranking government officials who will be able to use their influence to ensure the anticipated priority of the presidency-related affairs in state administration bodies. On the other hand, it is operationally essential to ensure good and continuous cooperation between and within ministries and other state administration bodies.

The research methodology will be based on the secondary, desk study, decisions and programme of the Government of the Republic of Croatia and the comparison of programme and results of the Slovenian Presidency.

Keywords: Presidency, The Council of the European Union, The Republic of Croatia, Slovenia, Preparation and Implementation, Challenge

\section{INTRODUCTION}

Due to the referendum decision of the United Kingdom to leave the Union and resign from the planned Presidency of the Council, based on the Council Decision, ${ }^{1}$ the Republic of Croatia will be chairing the Council from 1 January 2020, unplanned, instead in the second half of 2026.

Given the numerous duties of the presiding state, from the organization of a large number of events and meetings, to the financing of the Presidency itself and, on the other hand, the relatively modest experience of the Croatian administration in similar events, the preparation and implementation of the Presidency will be a major challenge for the Republic of Croatia. The issue of Brexit and the unknown composition of the next European Parliament summit are just some of the additional challenges that Croatia will face in the upcoming period.

The paper will present the organizational, financial and administrative aspect of the Presidency of the Council and will compare it with the example of Slovenia. Slovenia's experience in preparing and chairing the Council, in the opinion of the authors, can largely be applied to the Republic of Croatia and used to predict potential problems and solutions. The example of Slovenia was chosen because

Council Decision (EU) 2016/1316 amending Decision 2009/908/EU, laying down measures for the implementation of the European Council Decision on the exercise of the Presidency of the Council, and on the chairmanship of preparatory bodies of the Council, [2016] OJ L 208/42 
of the fact that it was also the first Presidency of the Council for Slovenia, as it is going be for Croatia, and that both states are "small" states, emerged from the former common state, with a relatively similar system of public administration. Slovenia has been chairing the Council since 1 January 2008, as part of the first Presidential Trio and, like Croatia is now, was a relatively young EU member state. ${ }^{2}$ Also, Slovenia and Croatia have both opted for the "Brussels" model of chairing the Council, where a significant part of the events and meetings are organized in Brussels. Furthermore, Slovenia and Croatia have established a similar organizational system for the preparation and implementation of the Presidency, a similar financial framework for the Presidency, and planned a similar human resource management policy and training of state and public officials who will participate in the preparation and implementation of the Presidency.

Due to these similarities, it can be assumed that the problems and challenges that Slovenia faced, in the same or similar form and scope, will very likely pose problems and challenges for the Republic of Croatia during the preparation and implementation of the Presidency of the Council.

\section{THE COUNCIL OF THE EUROPEAN UNION}

The Council of the European Union (further on; The Council) is a legislative institution of the Union which at the same time has certain executive powers. The Council, together with the European Parliament, participates in the creation and adoption of the Union's laws and budgets, aligns the policies of the EU Member States, develops EU foreign and security policies in line with the European Council's guidelines. Also, the Council is responsible for concluding international agreements between the EU and other states or international organizations. ${ }^{3}$

The Council is chaired by the Member States so as they rotate every 6 months. During the six-month period, the Presidency chairs meetings at all levels in the Council. The presidency is conducted through three-member groups, known as the "trio" that was introduced by The Lisbon Treaty. ${ }^{4}$ The Trio sets long-term goals and prepares a joint programme by defining the topics and main issues to be addressed by the Council over a period of 18 months.

The Republic of Slovenia is a member state of the EU since 1 May 2004

3 Đerđa, D., Institucionalni ustroj izvršne i upravne vlasti u Europskoj uniji, Proceedings of the Faculty of Law at the University of Rijeka, v. 28, no. 2., 2007, p. 1194.

4 European Commission, The European Union explained: How the EU works, 2014

[https://publications.europa.eu/hr/publication-detail/-/publication/9a6a89dc-4ed7-4bb9-a9f7-53d7f $1 \mathrm{fb} 1 \mathrm{dae}]$

Accessed 15.04.2019 
Based on this programme, all three countries prepare their detailed six-month programmes. The presiding country can influence EU policy by defining topics and creating agenda of the Council's meetings according to its own priorities. The Council does not have a permanent composition, but it is made up by the ministers of the EU Member States depending on the issues discussed at the session, i.e. it operates through ten different configurations, ${ }^{5}$ with the exception of the Foreign Affairs Council, which has a permanent chairman - the High Representative for Foreign Affairs and Security Policy. Representatives (Ministers or State Secretaries) of the Member States in the Council are authorized to assume the obligations on behalf of their state government. ${ }^{6}$

\subsection{The programme of the Romanian, Finnish and Croatian Presidency of the Council}

The 18-month programme ${ }^{7}$ of the Romanian, Finnish and Croatian Presidencies of the Council the member states confirmed on 11 December 2018 at a meeting of the General Affairs Council in Brussels. The Programme emphasizes the importance of the common values of the Union: respect for human dignity, freedom, democracy, equality, the rule of law and respect for human rights, among other rights of minorities. One of the priorities of the Presidencies will be the effective handling of the Brexit process. Also, one of the key tasks of the three Presidencies will be to help finalize the negotiations on the Multiannual Financial Framework for the period 2021-2027. The Joint Programme is based on five key priority areas: A Union for Jobs, Growth and Competitiveness, ${ }^{8}$ a Union That Empowers and Protects All Its Citizens, ${ }^{9}$ Towards an Energy Union with a Forward-looking

5 General Affairs Council; Foreign Affairs Council; Economic and Financial Affairs Council; Justice and Home Affairs Council; Employment, Social Policy, Health and Consumer Affairs Council; Competitiveness Council; Transport, Telecommunications and Energy Council; Agriculture and Fisheries Council; Environment Council; Education, Youth, Culture and Sport Council

6 Decisions in the Council are made by voting; by simple majority, by qualified majority and unanimity, depending on which matter they decide and in accordance with the treaties

7 Council of the European Union, 18-month Programme of the Council (1 January 2019-30 June 2020), 2018

[http://data.consilium.europa.eu/doc/document/ST-14518-2018-INIT/en/pdf] Accessed 12.03.2019

8 The Presidency will work on a single market and more integrated service market and digital economy, completing the digital single market

9 The three Presidencies will continue to work on implementation of policies aimed at strengthening social dimension, tackling skills mismatch 
Climate Policy, ${ }^{10}$ A Union of Freedom, Security and Justice, ${ }^{11}$ and the Union as a Strong Global Actor. ${ }^{12}$

Romania is the only country in the Trio of Presidencies that has so far presented its programme for Presidency to the EU Council by 30 June, 2019, as it began with the Presidency on 1 January this year. The official slogan of the Romanian Presidency is "Cohesion as a Common European Value". This programme is based on four main pillars; A convergence Europe, A safer Europe, Europe as a stronger global actor and A Europe of common values.

\section{THE ORGANIZATIONAL ASPECT OF THE PRESIDENCY OF THE COUNCIL OF THE EUROPEAN UNION}

The Slovenian government established an organizational structure for the preparation and implementation of the Presidency already in January $2005,{ }^{13}$ three whole years before the Presidency. Compared to Croatia, which did so 18 months before the Presidency, they had done it very early.

The Slovenian organizational structure consisted of the Task Force for Preparing for Presidency of the Council, which was tasked with making political decisions and establishing the programme and priorities of the Presidency, led by then Prime Minister Janez Janša. A Wider Working Group for Presidency of the Council was established as the main operating body to supervise the work of ministries and other state and public bodies. In addition to the Wider Working Group, a Working Group for Coordination of the Presidency Preparation was established, which cooperated with Germany and Portugal. Thematic subgroups have also been set up; Presidency Programme Subgroup, Human Resources Subgroup, Presidency Budget Subgroup, Public Relations and Promotion Subgroup, and Presidency Organization Subgroup. ${ }^{14}$

10 The three Presidencies intend to finalise the negotiations on the Clean Energy package, and on the proposals under the mobility packages, including in particular the climate-related initiatives

11 Since the period of application of the current Strategic Guidelines for the development of the area of freedom security and justice comes to an end together with the end of the institutional cycle, the three Presidencies have scheduled in the programme to take up the new guidelines to be elaborated by the European Council

12 The three Presidencies will work on taking forward the agreed priorities of the EU Global Strategy, ensuring the consistency of the EU's external policies

13 The Decision of the Government of the Republic of Slovenia no. 901 - 04 / 2004-2, 2005, Obrazložitev finančnega načrta Služba vlade Republike Slovenije za evropske zadeve, SPU 158, 2006, p. 7

14 Predlog za uvrstitev gradiva "Priprave na predsedovanje Slovenije EU”, Republic of Slovenia, Government Office for European Affairs, 2005, p. 3 
After the Slovenian Presidency ended, Kajnč and Svetličić ${ }^{15}$ conducted a research in 2008 to identify the key issues faced by the participants in the process of preparing and implementing the Presidency of the Council and the disadvantages of the Slovenian state and public administration, which hampered the preparation and implementation of the Presidency. Namely, according to the order of problems given by the research participants, poor vertical cooperation between the ministries is in the second place (15.6\%), followed by insufficient inter-institutional cooperation $(14.3 \%)$ and institutional hierarchy that prevents individual initiatives (12\%). Further, the same research has shown that the possible cause of the above-mentioned problems, which is the general conclusion of the research, is relatively weak cooperation between the ministries and within the ministry during the Presidency. Namely, the devastating is the fact that only $8 \%$ of respondents rated cooperation between ministries as excellent and $27.7 \%$ as good. Also, the research revealed that the Slovenian diplomatic network had not been sufficiently exploited, as $27.2 \%$ of respondents rated it very bad or bad. On the other hand, respondents rated best the cooperation with representatives of the Permanent Representation of the Republic of Slovenia to the European Union (47.1\% excellent, 26\% good).

The Republic of Croatia has established a structure for the preparation and implementation of the Presidency of the Council by the Government Decision of July $2018^{16}$. In accordance to the decision, the structure consists of the Steering Committee for Presidency which issues strategic decisions and guidelines for the preparation and implementation of the Presidency, whose permanent members are the President and Vice Presidents of the Government, the Permanent Representative of the Republic of Croatia to the EU, an official delegated to represent the Council in the EU Parliament and the Secretary of the Steering Committee, then the Inter-Ministerial Coordination Body ${ }^{17}$ which makes operational decisions, prepares strategic decisions, and coordinates activities for the preparation and implementation of the sessions. Members of this body are State Secretaries of Ministries, Head of Government Office, Permanent Representative of the Repub-

15 Kajnč, S.; Svetličić, M., What it Takes to Run an EU Presidency: Study of Competences in Slovenia's Public Administration. University of Ljubljana, Halduskultuur - Administrative Culture 11 (1), 2010, p. 99; research was conducted as an anonymous electronic survey with 40 questions sent to 667 addresses of state and public officials who participated in the Presidency. 407 responses were received $(235 \mathrm{com}$ plete and 172 incomplete)

16 Odluka o uspostavi strukture za pripremu i provedbu Predsjedanja Republike Hrvatske Vijećem Europske Unije 2020, Narodne Novine, no. 60/2018

17 According to Point 6 of the Decision on the Establishment of the Structure for the Preparation and Implementation of the Presidency of the Republic of Croatia of the Council of the European Union in 2020 
lic of Croatia to the EU and Secretary of the Inter-Ministerial Coordination Body. The Secretariat of the Presidency of the Republic of Croatia of The Council of Europe in 2020 as a constituent unit of the Ministry of the Foreign and European Affairs will perform the tasks of the Secretariat of the Steering Committee and the Inter-Ministerial Coordination Body. The Presidency Secretariat has established the Office for Organization and Logistics for Presidential Affairs, the Human Resources and Training Services for Presidency Affairs, the Communications Services and Cultural Activities for Presidency Affairs, the Procurement Department for Presidential Affairs. ${ }^{18}$ The Secretariat of the Presidency of the Republic of Croatia of the Council of the EU is supposed to have a total of 65 employees.

From the above it can be concluded that the Republic of Croatia, similarly to Slovenia, has opted for a highly ranked political body to govern the process of preparation and implementation of the Presidency. It certainly speaks about the importance of the Presidency for the Government of the Republic of Croatia.

Slovenia, at least when the current situation is considered, had been preparing for the Presidency longer and more systematically. Namely, at this point, 8 months before the Presidency, apart from the Action Plan for the Presidency, Croatia has no detailed elaborated planning and thematic documents. In an organizational sense, the Republic of Croatia will face, on the one hand, logistics activities, from space planning to the acquisition of cars for the Presidency, and on the other hand, more demanding tasks such as preparation of materials, documents and board meetings of the Council. Also, setting the agenda alone will be a challenge for the Republic of Croatia, since the experiences of other countries show that they have largely been forced to take on inherited agendas, which greatly affects the success of the Presidency and promotion of national interests. The assumption is that Croatia will not be able to resist it either.

\section{FINANCIAL ASPECT OF THE PRESIDENCY OF THE COUNCIL OF THE EUROPEAN UNION}

The Presidency of the Council of the European Union is an expense funded from the national budget, and only a small part intended for staff training can be financed by the EU funds. In 2005, Slovenia has opened an item in the budget intended for the expenses of the activities of the Presidency. Slovenian Presidency expenses were initially estimated at EUR 57,169,087.00, ${ }^{19}$ while the total actu-

\footnotetext{
18 Art.14 of Uredba o izmjenama i dopunama Uredbe o unutarnjem ustrojstvu Ministarstva vanjskih i europskih poslova, Narodne novine, no. 58/2018

19 Jerebič Minka, M., Priprave na predsedovanje Slovenije Evropski uniji, Uprava, Letnik, V, 2007, p.134
} 
al cost of the Slovenian Presidency amounted to EUR 62,374,158.00. ${ }^{20}$ For the comparison the expected expenditures for the Czech Presidency amount of EUR $73^{21}$ milion or Hungarian Presidency to EUR $80^{22}$ milion. The planned budget for the Slovenian presidency was well projected, which is a great success and an indication that coordination at the Slovenian budget line has been implemented efficiently.

In November 2018, the Government of the Republic of Croatia published a document Explanation of the State Budget of the Republic of Croatia for 2019 and the Projections for 2020 and 2021, ${ }^{23}$ which states that, according to sources of funding, the expenditures of the Presidency are financed from general revenues and receipts, contributions and dedicated receipts and for 2019 they amounted to EUR 15 million, an increase of 2.6 percent compared to the expenditures financed from these sources in the State Budget of the Republic of Croatia for 2018. In 2020, these expenditures are planned at the level of EUR 15.1 million, and in 2021 at the level of EUR 15.3 million.

The increase in the level of expenditures for 2019 is, among other things, justified by the provision of funds for the costs of preparing the Presidency of the Council in the amount of EUR 21.6 million. It should be noted that the cost involved includes the cost of organizing the Congress Centre of the National and University Library. ${ }^{24}$ Most ministries have ensured a separate item in the budget, which provided funds for the costs of activities related to the Presidency of the Council. Table no. 1. presents the sums of budget items for the Presidency of the Council of the European Union in 2020 by ministries. It is important to note that the Ministry of State Property and the Ministry of Croatian Veterans' Affairs do not have the funds for this activity, while the Ministry of the Interior does not have ensured separate budget activity directly related to the Presidency of the Council,

$20 \quad$ Predsedovanje Slovenije Svetu EU 2008 - v številkah

[http://www.eu2008.si/si/News_and_Documents/Press_Releases/June/0630UKOMstevilkePEU. html] Accessed 22.03.2019

21 Czech Presidency of the European Union

[http://www.eu2009.cz/en/czech-presidency/presidency-budget/presidency-budget-497/index.html] Accessed 30.03.2019

22 Institute for World Economics of the Hungarian Academy of Sciences, The Hungarian Presidency of the EU Council in a Nutshell, 2011

[www.vki.hu/sn_eng/sn-eng-29.pdf] Accessed 30.03.2019

23 Obrazloženje državnog proračuna Republike Hrvatske za 2019. godinu i projekcije za 2020. i 2021. godinu. Government of the Republic of Croatia, Zagreb, 2018., calculated at the Croatian National Bank's average exchange rate on 30 April 2019

24 Odluka o utvrdivanju nacionalne i sveučilišne knjižnice u Zagrebu jednim od središnjih prostora za provedbu aktivnosti predsjedanja Republike Hrvatske Vijećem Europske unije 2020 u Republici Hrvatskoj. Narodne Novine, no. 60/2018 
but has increased funds within the position of NATO and EU Activities allocated for expenses of staff stationed on duty abroad, for preparation and implementation of Council Presidency activities. This is similar to the budgets of the Ministry of Defence and the Ministry of Science and Education, which have increased resources for chairing activities within regular activities.

Table 1: Planned funds for the Presidency of the Council of the EU by the respective ministries (in million EUR)

\begin{tabular}{|c|c|c|c|c|}
\hline Budget user & $\begin{array}{c}\text { The amount of } \\
\text { secured funds in } \\
2019 \\
\end{array}$ & $\begin{array}{c}\text { The amount of } \\
\text { secured funds in } \\
2020 \\
\end{array}$ & TOTAL & $\begin{array}{l}\text { User's } \\
\text { share }\end{array}$ \\
\hline Ministry of Finance & 221.423 & 322.757 & 544.180 & $1,4 \%$ \\
\hline Ministry of the Foreign and European Affairs & 8.865 .013 & 14.340 .062 & 23.205 .074 & $59,2 \%$ \\
\hline Ministry of Economy, Enterprise and Crafts & 546.473 & 654.419 & 1.200 .892 & $3,1 \%$ \\
\hline Ministry of Culture & 32.303 & 32.461 & 64.763 & $0,2 \%$ \\
\hline Ministry of Agriculture & 409.645 & 1.028 .073 & 1.437 .718 & $3,7 \%$ \\
\hline Ministry of Regional Development and EU Funds & 86.032 & 43.003 & 129.035 & $0,3 \%$ \\
\hline Ministry of the Sea, Transport and Infrastructure & 2.089 .488 & 2.171 .051 & 4.260 .539 & $10,9 \%$ \\
\hline Ministry of Environmental Protection and Energy & 1.367 .428 & 1.730 .716 & 3.098 .144 & $7,9 \%$ \\
\hline Ministry of Construction and Physical Planning & 389.278 & 379.833 & 769.111 & $2,0 \%$ \\
\hline Ministry of Labour and Pension System & 360.807 & 360.807 & 721.615 & $1,8 \%$ \\
\hline Ministry of Justice & 787.461 & 1.015 .901 & 1.803 .362 & $4,6 \%$ \\
\hline Ministry of Public Administration & 53.973 & 82.578 & 136.551 & $0,3 \%$ \\
\hline Ministry of Health & 633.699 & 696.491 & 1.330 .190 & $3,4 \%$ \\
\hline Ministry of Demography, Family, Youth and Social Poli & 181.955 & 181.955 & 363.911 & $0,9 \%$ \\
\hline Ministry of Tourism & 43.853 & 78.463 & 122.316 & $0,3 \%$ \\
\hline TOTAL & 16.068 .831 & 23.118 .570 & 39.187.400 & $100,0 \%$ \\
\hline
\end{tabular}

Source: Made by the authors according to Explanation of the State Budget of the Republic of Croatia for 2019 and the Projections for 2020 and 2021

From the table above, it is apparent that the ministries secured EUR 16 million in the 2019 budget for the Presidency activities, while in 2020 they plan to spend EUR 23.1 million, i.e. the total costs of chairing for the ministries are planned at the level of EUR 39.1 million. Ministry of the Foreign and European Affairs as the main coordinating body of the state administration for preparing the Presidency of the Council is also the largest budget beneficiary with a share of $59.2 \%$, that is, with secured funds of EUR 23.2 million in 2019 and 2020. The ministries that allocated the largest amounts for the Presidency activities in the Budget are the Ministry of the Sea, Transport and Infrastructure with EUR 4.3 million and the Ministry of Environmental Protection and Energy with the planned EUR 3.1 million. The funds planned in the Budget for the activities of the Presidency mainly refer to the costs of paying the newly employed experts in working groups who will be staying in Brussels and associated material costs such as the cost of relocating staff and their family members, accommodation, transportation, health care etc. It is important to emphasize that ministries also included the costs of 
organizing meetings and conferences, education, procurement of IT-related and communication equipment.

From this it can be concluded that the financial plan for the Presidency is well planned and according to the experiences of other countries, realistic. It is not expected that there will be major deviations from the planned budget, nor will the financing of the Presidency significantly affect the economic image of the Republic of Croatia.

\section{ADMINISTRATIVE ASPECT OF THE PRESIDENCY OF THE COUNCIL OF THE EUROPEAN UNION}

The Government of the Republic of Slovenia had the task of finding the most optimal way of organizing human resource management, training of existing employees and new employment. Slovenia optimised the working processes in three ways: merging working fields, having one person in charge of several domains and entrusting the staff with preliminary experience of the field to handle the tasks at hand. ${ }^{25}$ According to the Slovenian Government's 2009 report ${ }^{26} 2755$ civil and public officials, ${ }^{27} 133$ external experts and 245 students participated in the Presidency of Slovenia. The Government of the Republic of Slovenia had planned 315 new jobs solely for the Presidency, and ultimately achieved the number of 289 newly employed. ${ }^{28}$

In order to train the personnel for the Presidency, the Slovenian Government had adopted the Personnel Plan for the Slovenian Presidency of the EU Council. ${ }^{29}$ The plan provided a training programme divided into three groups: the functioning of the EU and its institutions, the development of skills for organization and implementation and improving foreign languages (English and French). 856 officials and state and public servants participated in the training programme. ${ }^{30}$

25 Svetličić, M.; Cerjak, K., Small Countries' EU Council Presidency and the Realisation of their National Interests: The Case of Slovenia, CIRP XXI, 74, 2015, p. 15

26 Kadrovsko poročilo za leto 2008. Ministarstvo za javno upravo, Ljubljana, 2009, p.18

272610 civil servants in Ljubljana and 165 in the Permanent Representation of the Republic of Slovenia to the EU, of which 1151 civil servants were included in the programme part, and the other 1624 in the organizational and logistic part of the preparation and implementation

28148 in Ljubljana, 116 in Permanent Representation, and 25 in diplomatic missions

29 The Decision of the Government of the Republic of Slovenia no. 10002-5 / 2005/27, 2005: Obrazložitev finančnega načrta Služba vlade Republike Slovenije za evropske zadeve, SPU 31, 2008, p. 8

30 Participants of the training were ministers and state secretaries (34), chairmen of European committees and deputies (240), national representatives and experts (250), administrative staff (160), official speakers and public relations experts (50), coordinators 50), translators and interpreters (72) 
In addition to the training programme, the following manuals for the Slovenian Presidency were issued, which facilitated the participants accomplishment of their tasks: General Guide to the Ministers on the Presidency of the Council of the EU, Handbook for Presidency of Working Groups of the Council of the European Union, Handbook for Cooperation with the European Parliament, Handbook for Assistance in Organizing Events at the Ministerial and High Levels During the Slovenian Presidency of the Council of the EU, Handbook for Assisting in Organizing Events Below the Ministerial Level During the Slovenian Presidency of the Council of Europe, and Handbook for Officials and Speakers and Public Relations Offices. $^{31}$

Slovenian experience shows that the greatest problem and challenge during the preparation and implementation of the Presidency of the Council is a lack of skilled and trained public and civil servants. This is supported by the results of the

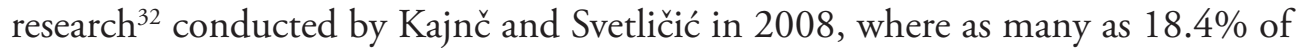
respondents rated the human capacity deficit as the biggest problem. Insufficient knowledge of similar areas was also highlighted as a problem (10.5\%), followed by the lack of information on the relevant issue (8.6\%), internal political issues $(8.6 \%)$, poor knowledge of the functioning of EU institutions $(6.6 \%)$ and insufficient knowledge of the area of activity (5.3\%).

The Ministry of the Foreign and European Affairs of Croatia has already in its Strategic Plan for the period 2018-2020 $0^{33}$ highlighted civil servants training as a key challenge for successful preparation and implementation of the Presidency. In 2016, the Government of the Republic of Croatia adopted the Action Plan for Implementation of the Public Administration Development Strategy, which stipulates that in the second quarter of 2019, 450 civil servants will be trained to work in the preparatory bodies of the Council and on preparing the Presidency programme. ${ }^{34}$ Civil servants will be educated through the project "Enhancing knowledge, skills and professional competences of state and public officials for representation of national interests" 35 carried out by the Ministry of the For-

31 Zadnik, V., Predsedovanje slovenije Svetu EU, Ljubljana, 2009, master's thesis, p. 76

32 Kajnč; Svetličić, op. cit., note 15, p. 99

33 Strateški plan za razdoblje 2018.-2020. Ministry of the Foreign and European Affairs, Zagreb, 2018, p. 32

34 Mjera 3.8. Akcijskog plana provedbe strategije razvoja javne uprave za razdoblje od 2017. do 2020. godine, The Government of the Republic of Croatia, 2016, p.16

35 State Public Administration School [https://dsju.hr/dsju/news_detail/potpisan-ugovor-o-dodjeli-bespovratnih-sredstava-za-projekt-unaprjedenje-znanja-vjestina-i-strucnih-kompetencija-drzavnih-i-javnih-sluzbenika-za-zastupanje-nacionalnih-interesa-17-12-2018] Accessed 05.03.2019 
eign and European Affairs in cooperation with the State Public Administration School. ${ }^{36}$

The aim of the project is to enable state and public officials, as well as the Permanent Representation of Croatia to the EU personnel, to prepare and implement the Croatian Presidency of the Council. The project plans the training of 800 officials through 276 days of education. Unlike Slovenian, the Croatian training programme includes two types of education: the first refers to improving knowledge of EU functioning and decision-making within institutions, and the second type of education is aimed at improving negotiation skills at EU working groups, written reporting techniques, meetings management and improving knowledge of professional English and French.

Similar to Slovenia, it can be assumed that there will be a need for recruiting additional qualified personnel in the public administration for the purpose of preparing and implementing the Presidency of the Council. Accordingly, the Budget is designed with new employment in mind in most ministries, and in particular the Ministry of the Foreign and European Affairs that will employ additional 40 employees for diplomatic-protocol activities in the Permanent Representation of Croatia to the EU, the Ministry of Environmental Protection and Energy with the planned 49 new jobs, then the Ministry of Health with 20 newly employed persons, the Ministry of the Sea, Transport and Infrastructure with 15 newly employed persons and the Ministry of Demography with 3 new advisors and 3 expert associates. ${ }^{37}$

The authors' recommendation is that as soon as possible Croatia should make specific decisions on human resource management for the needs of the Presidency and special guidebooks to provide specific guidelines for the activities of officials, employees and external experts.

Existing staff training will be key to successful preparation and implementation of the Presidency, especially if we consider the results of Slovenian research as well as the inexperience in organizing and implementing similar events. Also, the challenge for the Republic of Croatia will be the motivation of skilled employees, as well as external experts to be ready to participate in the implementation of the Presidency, therefore it is very important to establish a rewarding system for the best employees.

\footnotetext{
36 The project is funded from the European Funds under the Operational Programme Human Resources 2014-2020. The total budget of the project is HRK 7,353,364, of which the EU co-financing amounts to $85 \%$ and the national share to $15 \%$

37 Obrazloženje državnog proračuna Republike Hrvatske za 2019. godinu i projekcije za 2020. i 2021. godinu, The Government of the Republic of Croatia, Zagreb, 2018
} 


\section{CONCLUSION}

In the context of the Croatian Presidency of the Council, a research conducted by Think Tank EUROPA ${ }^{38}$ is interesting, according to which the ministers of the Government of the Republic of Croatia participated in only $56 \%$ of the Council meetings, which is considerably less than the average of $76 \%$. This information is not representative of Croatia as a relatively young member state, which does not have sufficient influence on the EU policy-making or coalition potential, and on the other hand, it is now preparing the Presidency of the Council. Similar situation is with the Slovenian ministers, who participated in $55 \%$ of the Council meetings.

Bearing in mind that Slovenia started its preparations for the Presidency of the Council already in January 2005, relatively early, three years before the Presidency, and on the other hand, that Croatia's term of the Presidency was not officially confirmed until 2016 and the Government has set up the organizational structure for the preparation and implementation of the Presidency in July 2018, we can conclude that the 18 months period is a very short time for the organization of the Presidency and that Croatia is in a "time crunch".

It can be assumed that organizationally, financially and administrative-logistically, preparation and implementation of the Presidency will be extremely demanding for the Republic of Croatia. Slovenia's experiences and research results suggest that the biggest problems for the Republic of Croatia will be organizational and administrative-logistic capacities. First of all, the problem could be the lack of specialized skills and experience of state and public officials for the preparation and implementation of events such as chairing the Council, lack of knowledge of the subject, i.e. poor knowledge of public and civil servants on the EU, the way of functioning of EU institutions, decision-making and policy implementation. Therefore, it is extremely important that the selection of officials and external experts who will participate in the preparation and implementation of the Presidency is deprived of political criteria, but to be carried out solely on the criteria of professional qualifications and competences. This will also minimize the impact of internal political issues and possible political turbulence on the process of the preparation and implementation of the Presidency of the Council. Furthermore, it is of utmost importance to have a high-quality and efficient implementation of education and training programmes for state and civil servants in order to maxi-

38 Think Tank EUROPA, [http://english.thinkeuropa.dk/politics/danish-ministers-show-less-average-council-meetings] Accessed 05.03.2019. The research was conducted according to the list of participants in the period from June 2015 to August 2018 
mize their degree of readiness and at least partially avoid or reduce the problems with the human resources that Slovenia had encountered.

To conclude, establishment of the presented governance structure of the Croatian Presidency can be positively assessed and it can be assumed that for the successful preparation and implementation of the Presidency of the Council, it is good that the members of the governing body are high-ranking government officials who will be able to use their influence to ensure the anticipated priority of the presidency-related affairs in state administration bodies. On the

other hand, it is operationally essential to ensure good and continuous cooperation between and within ministries and other state administration bodies in order to avoid repeating the problems Slovenia faced during the Presidency.

\section{REFERENCES}

\section{BOOKS AND ARTICLES}

1. Đerđa, D., Institucionalni ustroj izvršne i upravne vlasti u Europskoj uniji. Proceedings of the Faculty of Law at the University of Rijeka, vol. 28, no. 2., 2007, pp. 1185-1218

2. Jerebič Minka, M., Priprave na predsedovanje Slovenije Evropski uniji, Uprava, Letnik, V, 2007, pp. 121-141

3. Kajnč, S.; Svetličić, M., What it Takes to Run an EU Presidency: Study of Competences in Slovenia's Public Administration. University of Ljubljana, Halduskultuur - Administrative Culture 11 (1), 2010, pp. 84-109

4. Svetličić, M., Cerjak, K., Small Countries' EU Council Presidency and the Realisation of their National Interests: The Case of Slovenia, CIRP XXI, 74, 2015, pp. 5-39

5. Zadnik, V., Predsedovanje slovenije Svetu EU, Ljubljana, 2009, master's thesis

\section{EU LAW}

1. Council Decision (EU) 2016/1316 amending Decision 2009/908/EU, laying down measures for the implementation of the European Council Decision on the exercise of the Presidency of the Council, and on the chairmanship of preparatory bodies of the Council, [2016] OJ L 208/42

\section{LIST OF NATIONASL REGULATIONS, ACTS AND COURT DECISIONS}

1. Kadrovsko poročilo za leto 2008. Ministarstvo za javno upravo, Ljubljana, 2009

2. Obrazloženje državnog proračuna Republike Hrvatske za 2019. godinu i projekcije za 2020. i 2021. godinu. The Government of the Republic of Croatia, Zagreb, November 2018

3. Obrazložitev finančnega načrta Služba vlade Republike Slovenije za evropske zadeve, SPU 158, 2006 
4. Odluka o utvrđivanju nacionalne i sveučilišne knjižnice u Zagrebu jednim od središnjih prostora za provedbu aktivnosti predsjedanja Republike Hrvatske Vijećem Europske unije 2020 u Republici Hrvatskoj. Narodne Novine, no. 60/2018

5. Odluka o uspostavi strukture za pripremu i provedbu Predsjedanja Republike Hrvatske Vijećem Europske unije 2020, Narodne Novine no. 60/2018

6. Predlog za uvrstitev gradiva „Priprave na predsedovanje Slovenije EU“, Služba Vlade Republike Slovenije za Evropske zadeve, 2005

7. Uredba o izmjenama i dopunama Uredbe o unutarnjem ustrojstvu Ministarstva vanjskih $i$ europskih poslova, Narodne Novine no. 58/2018

\section{WEBSITE REFERENCES}

1. Czech Presidency of the European Union

[http://www.eu2009.cz/en/czech-presidency/presidency-budget/presidency-budget-497/index.html] Accessed 30.03.2019

2. European Commission, The European Union explained: How the EU works, 2014 [https://publications.europa.eu/hr/publication-detail/-/publication/9a6a89dc-4ed7-4bb9a9f7-53d7flfbldae] Accessed 15.03.2019

3. Institute for World Economics of the Hungarian Academy of Sciences, The Hungarian Presidency of the EU Council in a Nutshell, 2011 [www.vki.hu/sn_eng/sn-eng-29.pdf] Accessed 30.03.2019

4. Predsedovanje Slovenije Svetu EU 2008 - v številkah [http://www.eu2008.si/si/News_and_Documents/Press_Releases/June/0630UKOMstevilkePEU. html] Accessed 22.03.2019

5. State Public Administration School [https://dsju.hr/dsju/news_detail/potpisan-ugovor-o-dodjeli-bespovratnih-sredstava-zaprojekt-unaprjedenje-znanja-vjestina-i-strucnih-kompetencija-drzavnih-i-javnih-sluzbenika-za-zastupanje-nacionalnih-interesa-17-12-2018] Accessed 05.03.2019

6. Think Tank EUROPA

[http://english.thinkeuropa.dk/politics/danish-ministers-show-less-average-council-meetings] Accessed 05.03.2019 